\title{
PENGARUH KOMPETENSI KEPRIBADIAN DAN KOMPETENSI PEDAGOGIK GURU TERHADAP PRESTASI BELAJAR SISWA KELAS VIII SMP NEGERI 1 SUKATANI
}

\author{
${ }^{1}$ Fernando Saragih, ${ }^{2}$ Jesika Theresia Sihotang \\ 1,2Universitas Pendidikan Indonesia \\ 1Email : fernandosaragih78@yahoo.co.id \\ Email : jesika280195@gmail.com
}

\begin{abstract}
ABSTRAK
Penelitin ini bertujuan untuk menganalisis apakah kompetensi kepribadian dan kompetensi pedagogik guru berpengaruh positif dan signifikan terhadap prestasi belajar pada kelas VIII mata pelajaran IPS. Penelitian menggunakan metode survey dengan teknik penyebaran angket kepada 40 responden dan teknik analisis data menggunakan analisis regresi berganda, asumsi klasik dan uji hipotesis. Hasil penelitian menunjukkan bahwa kompetensi kepribadian dan kompetensi pedagogik guru berpengaruh positif dan signifikan terhadap prestasi belajar siswa yaitu $Y=24,487+1,494 X 1+0,914 \mathrm{X} 2$ dan hasil ini juga diperkuat dengan hasil uji $\mathrm{T}$ dan uji $\mathrm{F}$ dimana variabel kompetensi kepribadian dan kompetensi pedagogik memiliki nilai $t$ hitung $>t$ tabel yaitu 2,931>1.69726 dan 2,110>1.69726 sedangkan pada f hitung diperoleh niai 10,875. Hal ini menunjukkan bahwa fhitung $>$ ftabel $(10,875>3,35)$, sehingga dapat disimpulkan bahwa semakin tinggi kompetensi kepribadian dan kompetensi pedagogik guru maka semakin tinggi pula prestasi belajar siswa.
\end{abstract}

\section{PENDAHULUAN}

Sumber daya manusia yang berkualitas merupakan hal yang sangat penting pada era globalisasi ini. Dimana, sumber daya manusia yang berkualitas merupakan salah satu kunci kemajuan suatu negara. Peningkatan kualitas sumber daya manusia merupakan hal yang mutlak dan harus dilakukan. Salah satu cara yang dapat dilakukan untuk meningkatkan kualitas sumber daya manusia adalah melalui peningkatan kualitas pendidikan. "Kualitas pendidikan ini dianggap penting karena sangat menentukan gerak laju pembangunan di negara manapun juga" (Lailatussaadah 2015:15). Peningkatan kualitas pendidikan dapat dilihat prestasi belajar peserta didik. Prestasi siswa yang baik menandakan bahwa kualitas pendidikan juga baik. Salah satu faktor yang memperngaruhi prestasi belajar siswa yakni kompetensi guru dalam mengajar. Menurut Janawi (2011: 34) kompetensi diartikan sebagai "kemampuan, keahlian, dan keterampilan yang mutlak dimiliki oleh seseorang (dalam hal ini guru"). Kompetensi guru itu sendiri terdiri dari 4 dimana menurut UU No 14 tahun 2005 pasal 10 menjelaskan bahwa kompetensi guru sebagaimana dimaksud pasal 8 meliputi kompetensi pedagogik, kompetensi kepribadian, kompetensi sosial, dan kompetensi profesional yang diperoleh melalui pendidikan profesional. Selain itu menurut Edi Hendri (2010: 3) menjelaskan bahwa "Guru profesional adalah guru yang memiliki keahlian, tanggung jawab, dan rasa kesejawatan yang didukung oleh etika profesi yang kuat". Sedangkan menurut Cooper dalam Nana Sudjana (2002: 17) menyatakan bahwa ada empat kompetensi yang harus dimiliki guru, yaitu:

1. Mempuyai pengetahuan tentang belajar tingkah laku manusia.

2. Mempunyai pengetahuan dan menguasai bidang studi yang dibinanya.

3. Mempunyai sikap yang tepat tentang dirinya, sekolah, teman sejawat dan bidang studi yang dibinanya.

4. Mempunyai kemampuan tentang teknik mengajar

Oleh karena itu, kompetensi guru memiliki peranan yang penting. Namun kenyataannya masih banyak guru yang memiliki kompetensi dibawah standar yang ditentukan. Hal ini 
terlihat dari hasil uji kompetensi yang dilakukan, dimana hampir $41 \%$ guru di bandung dinyatakan tidak lulus kompetensi.

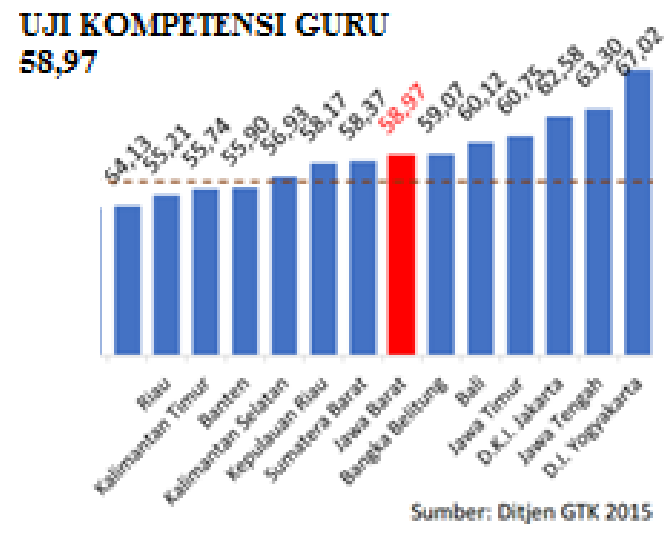

Gambar 1.1 Uji Kompetensi Nasional

Kondisi ini berbanding terbalik dengan negara lain. Dimana, guru telah dipersiapkan dengan baik. Hal ini terlihat dari pemberian sertifikat pendidikan yang telah diterapkan lebih dahulu, sehingga guru yang tersedia memiliki standar yang jelas dan baik. Salah satu negara yang telah menerapkan kebijakan ini adalah di negara maju seperti Amerika Serikat.

Oleh karena itu, pemerintah harus mengupayakan berbagai hal untuk mendongkrak dan meningkatkan kompetensi guru agar guru memiliki kinerja yang baik, misalnya dengan memberikan peluang untuk menempuh pendidikan yang lebih tinggi, mewajibkan semua guru untuk menempuh pendidikan minimal strata satu, memberikan pelatihan/seminar dan memberikan tunjangan serfikasi (Lailatussaadah 2015:17).

Dengan rendahnya tingkat kompetensi yang dimiliki oleh guru khususnya kompetensi pedagogik, akan berdampak langsung terhadap prestasi siswa. Hal ini dapat dilihat dari rendahnya nilai ujian siswa. Dimana hasil yang terendah yaitu 55,8 di peroleh siswa di SMA IPS sedangkan nilai tertinggi diperoleh dari siswa SMP yaitu 58,6.

Nas. $58,6 \quad 56,9 \quad 52,8 \quad 58,5$

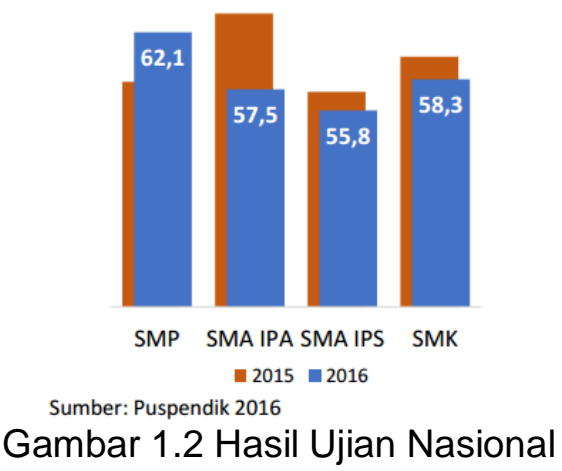

Selain berdampak kepada prestasi siswa, kompetensi guru yang rendah khususnya kompetensi kepribadian juga menyebakan kurangnya pengendalian diri dari seorang guru sehingga menimbulkan kasus seperti kekerasan fisik dan prilaku yang belawanan dengan tujuan pendidikan. Hal ini diperjelas dengan adanya peningkatan kasus kekerasan di sekolah dimana pada tahun 2011 terjadi 276 kasus dan pada tahun 2012 bertambah menjadi 522.

Oleh karena itu berdasarkan pemaparan di atas, penelitian ini akan berfokus untuk melihat pengaruh kompetensi kepribadian dan kompetensi pedagogik terhadap prestasi siswa. Dari perumusan masalah tersebut dapat dilihat bahwa penelitian ini bertujuan untuk melihat bagaimana pengaruh kompetensi kepribadian dan kompetensi pedagogik terhadap prestasi siswa. Dimana data yang diperoleh akan digambarkan melalui regresi berganda 
dan diperkuat dengan fakta yang terjadi di sekolah sehingga sekolah dapat mengambil langkah evaluasi agar terciptanya pembelajaran yang efisien.

\section{LANDASAN TEORI}

\section{Kompetensi Kepribadian}

Kompetensi kepribadian merupakan hal yang penting dalam diri seorang guru. Hal ini dikarenakan kompetensi kepribadian sangat besar pengaruhnya terhadap pertumbuhan dan perkembangan pribadi para peserta didik. Kepribadian adalah sesuatu sikap atau tingkah laku yang dimiliki oleh seseorang dalam melaksanakan suatu kegiatan yang menjadi tanggung-jawabnya untuk menentukan suatu tujuan (Sussana 2014: 378). Oleh karena itu kepribadian memiliki peranan yang penting dalam menentukan prestasi belajar. Hal ini seperti yang dijelaskan Syah dalam Purwanti (2013: 1075) dimana kepribadian itulah yang akan menentukan apakah ia menjadi pendidik dan pembina yang baik bagi anak didiknya, ataukah akan menjadi perusak atau penghancur bagi masa depan anak didiknya terutama bagi anak didik yang masih kecil (tingkat dasar) dan mereka yang sedang mengalami kegoncangan jiwa (tingkat menengah). Untuk itulah Guru harus mampu mengubah konsep diri mereka sebelum mereka dapat menimbulkan perubahan untuk keadaan yang lebih baik dalam konsep diri murid-murid mereka (Nursyamsi 2014: 32). Oleh karena ada beberapa nilai-nilai dasar yang harus dimiliki guru dalam kepribadiannya. Hal ini seperti yang dipaparkan oleh Purwanti (2013: 1078) yaitu

1. Kemantapan dalam bertindak

2. Kestabilan dalam emosi

3. Kedewasaan

4. Kearifan dan kebijaksanaan

5. Memiliki kewibawaan

6. Menunjukkan akhlak mulia

7. Menunjukkan keteladanan bagi peserta didik dan lingkungan masyarakat

8. Mampu menilai kinerja sendiri

9. Mampu mengembangkan diri secara berkelanjutan.

Hal ini sejalan dengan pendapat Ahwy Oktradiksa (2015:237) dimana kepribadian yang sehat diartikan kepribadian yang secara fisik dan psikis terbebas dari penyakit tetapi bisa juga diartikan sebagai individu yang secara psikis selalu berusaha menjadi sehat. Adapun indikator yang terdapat pada kepribadian yaitu bertanggung jawab, tidak emosional, lemah lembut. tegas, dekat dengan anak didik. Dengan tertanammnya nilai-nilai kepribadian tersebut maka akan terbentuklah guru yang berkepribadian yang baik dan mampu meningkatkan prestasi belajar. Hal ini sejalan dengan hasil penelitian yang dilakukan Darojah (2016:122) dimana diperoleh hasil $Y=53,836+0,217 \mathrm{X}$. Hal ini menunjukkan terdapat hubungan yang positif antara kompetensi kepribadian dengan prestasi belajar siswa, sehingga semakin tinggi kompetensi kepribadian guru, maka semakin tinggi pula prestasi belajar siswa. Selain itu diperoleh juga nilai Fhitung $\geq$ Ftabel atau 7,12 $\geq 3,946$ dimana hal ini menunjukkan terdapat pengaruh yang signifikan dari kompetensi kepribadian guru terhadap prestasi belajar siswa. Hal yang sama juga ditunjukkan pada penelitian Rohmah (2015:28) yaitu $Y=56,484+0,138 X_{1}+0,118 X_{2}+0,154 X_{3}$. Dimana nilai kompetensi kepribadian ditujukkan oleh 0,118X2. Hal ini menunjukkan terdapat hubungan yang positif antara kompetensi kepribadian dengan prestasi belajar siswa. Sehingga semakin tinggi kompetensi kepribadian guru, maka semakin tinggi pula prestasi belajar siswa 


\section{Kompetensi pedagogik}

Kompetensi pedagogik merupakan kompetensi yang penting. Menurut Agus Wibowo dan Hamrin (2012: 110) kompetensi pedagogik adalah pemahaman guru terhadap anak didik, perencanaan, pelaksanaan pembelajaran, evaluasi hasil belajar, dan pengembangan anak didik untuk mengaktualisasikan potensi yang dimilikinya dan untuk mencapai hasil belajar siswa yang baik. Berdasarkan pengertian di atas kompetensi ini memiliki peranan khusus, hal ini dikarenakan kompetensi pedagogik berkaitan langsung dengan penguasaan disiplin pendidikan dan ilmu lain yang berkaitan dengan tugasnya sebagai guru (Luh Retiantari 2014:4). Oleh karenanya kompetensi pedagogik bisa dikatakan sebagai gambaran dari proses pembelajaran. Dimana proses pembelajaran yang dilakukan guru diharapkan dapat menarik perhatian siswa untuk belajar. Konsekuensinya keterampilan mengajar di dalam kelas harus disiapkan sebaik mungkin agar menimbulkan persepsi siswa yang positif sebagai stimulus awal dalam proses pembelajaran (Umar 2014: 98). Oleh karena itu guru harus memahami makna yang terkandung dalam kompetensi pedagogik. Secara teknis kompetensi pedagogik Ini meliputi (Luh Retiantari 2014 :3) :

1. Menguasai karakteristik peserta didik

2. Menguasai teori dan prinsip-prinsip pembelajaran.

3. Mengembangkan kurikulum dan rancangan pembelajaran.

4. Menyelenggarakan pembelajaran yang mendidik.

5. Memanfaatkan tujuan instruksional khusus untuk kepentingan pembelajaran.

6. Menfasilitasi pengembangan potensi peserta didik.

7. Berkomunikasi secara efektif, empatik, dan santun dengan peserta didik.

8. Menyelenggarakan evaluasi dan penilaian proses dan hasil belajar.

9. Memanfaatkan hasil evaluasi dan penilaian untuk kepentingan pembelajaran.

10. Melakukan tindakan reflektif untuk peningkatan kualitas pembelajaran.

Sedangkan menurut Undanga-Undang mengenai Standar Nasional Pendidikan, Pasal 28 Ayat (3) butir (a) dikemukakan bahwa kompetensi pedagogik adalah kemampuan mengelolah pembelajaran peserta didik yang meliputi pemahaman terhadap peserta didik, perancanaan dan pelaksanaan pembelajaran, evaluasi hasil belajar, dan pengembangan peserta didik. Dengan tertanamnya nilai-nilai dari kompetensi pedagogik maka hal ini akan meningkatkan prestasi peserta didik. Hal ini sejalan dengan penelian Luh Retiantari (2014:9) dimana diperoleh hasil $\hat{Y}=12,649+0,779$ X1 $+0,102$ X2 berdasarkan hasil tersebut diketahui bahwa kompetensi pedagogik memiliki pengaruh yang besar yaitu 0,779 . Dimana hal ini menujukkan adanya hubungan yang positif dan signifikan antara kompetensi pedagogik dan prestasi belajar. Hal yang sama juga terlihat dari hasil penelitian Nawal Ika (2015: 136 ) dimana diperoleh hasil $Y=54,664+0,297 X$ dimana berdasarkan hasil tersebut diketahui bahwa kompetensi pedagogik memiliki pengaruh yang besar yaitu 0,297. Dimana hal ini menujukkan adanya hubungan yang positif dan signifikan antara kompetensi pedagogik dan prestasi belajar. Adapun hipotesis dalam penelitian ini adalah :

$\mathrm{Ha}_{1}$ : Terdapat pengaruh kompetensi kepribadian terhadap prestasi belajar.

$\mathrm{Ha}_{2}$ : Terdapat pengaruh kompetensi pedagogik terhadap prestasi belajar.

$\mathrm{Ha}_{3}$ : Terdapat pengaruh antara kompetensi kepribadian dan kompetensi pedagogik terhadap prestasi belajar.

\section{METODOLOGI}

Jenis penelitian ini adalah penelitian ex post facto. Penelitian ex post facto adalah suatu penelitian yang dilakukan untuk meneliti peristiwa yang telah terjadi dan kemudian meruntut kebelakang untuk mengetahui faktor-faktor yang dapat menimbulkan kejadian tersebut. Penelitian ini untuk mencari pengaruh variabel bebas terhadap variabel terikat. Penelitian ini dilakukan untuk mengetahui pengaruh kompetensi kepribadian dan kompetensi pedagogik 
terhadap prestasi belajar siswa. Data yang terkumpul berupa angka-angka, maka analisis yang digunakan adalah analisis kuantitatif. Penelitian akan dilakukan di SMP Negeri 1 Sukatani. Subyek dalam penelitian ini adalah siswa kelas VIII, sedangkan obyeknya adalah kompetensi kepribadian, kompetensi pedagogik dan prestasi belajar siswa. Jenis data dalam penelitian ini adalah data kuantitatif. Data kuantitatif adalah data yang berupa angka-angka. Data kuantitatif dalam penelitian ini yaitu hasil penelitian berupa kuesioner dan nilai UAS mata pelajaran IPS kelas VIII tahun ajaran 2016/2017.

Sumber data, berdasarkan sumbernya, data yang digunakan dalam penelitian ini adalah data primer dan data sekunder. Data primer berupa skor hasil kuesioner yang diperoleh dalam survei dengan menggunakan kuesioner yang diberikan kepada siswa kelas. Data skunder diperoleh dari hasil nilai ujian semester. Populasi adalah wilayah generalisasi yang terdiri atas obyek atau subyek yang mempunyai kualitas dan karakteristik tertentu yang ditetapkan oleh peneliti untuk dipelajari dan kemudian ditarik kesimpulannya (Sugiyono 2010: 115). Populasi dari penelitian ini adalah jumlah seluruh siswa kelas VIII, sedangkan jumlah sampel yang akan digunakan dalam penelitian ini adalah berjumlah 40 siswa. Metode kuesioner merupakan teknik pengumpulan data yang dilakukan dengan cara memberikan seperangkat pertanyaan yang disusun dengan pola skala likert 1 sampai 4 kepada responden. Kuesioner diberikan kepada siswa kelas X. Kuesioner digunakan untuk memperoleh data mengenai pengaruh kompetensi kepribadian dan kompetensi pedagogik terhadap prestasi belajar siswa. Analisis data dilakukan untuk menguji hipotesis yang diajukan, yaitu untuk mengetahui ada tidaknya hubungan antara variabel bebas $(X)$ dengan variabel terikat $(Y)$. Sedangkan teknik analisis yang digunakan dalam penelitian ini adalah regresi linear ganda dengan menggunakan program SPSS. Dimana pada penelitian ini menggunakan Uji Instrument, Uji asumsi klasik, Analisis, analisis regresi berganda dan uji hipotesis.

\section{HASIL DAN PEMBAHASAN}

\section{Uji Instrument}

Penelitian ini diawali dengan uji validitas dan reliabilitas, dimana Pengujian validitas dalam penelitian ini dilakukan dengan cara mengkorelasikan skor masing-masing pernyataan item yang ditujukan ke pada responden dengan total skor untuk seluruh item. Teknik korelasi yang digunakan untuk menguji validitas butir pernyataan dalam penelitian ini adalah korelasi Pearson Product Moment.

Tabel 1.1 Tingkat validitas kompetensi kepribadian

\begin{tabular}{|c|c|c|c|}
\hline No & T. validitas & $r_{\text {tabel }}$ & Ket \\
\hline 1 & 0,471 & 0,3673 & valid \\
\hline 2 & 0.525 & 0,3673 & valid \\
\hline 3 & 0,533 & 0,3673 & valid \\
\hline 4 & 0,467 & 0,3673 & valid \\
\hline 5 & 0,499 & 0,3673 & valid \\
\hline 6 & 0,542 & 0,3673 & valid \\
\hline 7 & 0,547 & 0,3673 & valid \\
\hline
\end{tabular}

Tabel 1.2 Tingkat validitas kompetensi pedagogik

\begin{tabular}{|c|c|c|c|}
\hline No & T. Validitas & $\mathrm{R}_{\text {tabel }}$ & Ket \\
\hline 1 & 0,558 & 0,3673 & valid \\
\hline 2 & 0,452 & 0,3673 & valid \\
\hline 3 & 0,570 & 0,3673 & valid \\
\hline 4 & 0,625 & 0,3673 & valid \\
\hline 5 & 0,490 & 0,3673 & valid \\
\hline 6 & 0,514 & 0,3673 & valid \\
\hline 7 & 0,458 & 0,3673 & valid \\
\hline
\end{tabular}


Berdasarkan hasil pengujian validitas diketahui bahwa seluruh angket valid, hal ini dikarenakan tingkat validitas $>r$ tabel. Hal ini sejalan dengan hasil uji reliabilitas dimana hasilnya didasarkan tabel Cronbach's Alpha yaitu :

Tabel 1.3 Nilai Cronbach's Alpha

\begin{tabular}{|c|c|}
\hline Nilai Cronbach's Alpha & Tingkat Keandalan \\
\hline $0.0-0.20$ & Kurang Andal \\
\hline$>0.20-0.40$ & Agak Andal \\
\hline$>0.40-0.60$ & Cukup Andal \\
\hline$>0.60-0.80$ & Andal \\
\hline$>0.80-1.00$ & Sangat Andal \\
\hline
\end{tabular}

Sehingga kompetensi kepribadian dapat dikatakan reliabel dan hal ini dikarenakan nilai Cronbach's Alpha berada pada kategori $>0.40-0.60$ yang memiliki arti cukup andal (reliabel)

Tabel 1.4 Reliabilitas angket kompetensi kepribadian

Reliability Statistics

\begin{tabular}{|r|r|}
\hline $\begin{array}{c}\text { Cronbach's } \\
\text { Alpha }\end{array}$ & N of Items \\
\hline, 520 & 7 \\
\hline
\end{tabular}

Sedangkan kompetensi pedagogik dapat dikatakan reliabel. Hal ini dikarenakan nilai Cronbach's Alpha berada pada kategori $>0.40-0.60$ yang memiliki arti cukup andal (reliabel)

Tabel 1.5 Reliabilitas angket kompetensi pedagogik

Reliability Statistics

\begin{tabular}{|r|r|}
\hline $\begin{array}{c}\text { Cronbach's } \\
\text { Alpha }\end{array}$ & $\begin{array}{c}\mathrm{N} \text { of } \\
\text { Items }\end{array}$ \\
\hline, 559 & 7 \\
\hline
\end{tabular}

\section{Uji Asumsi Klasik Uji Normalitas}

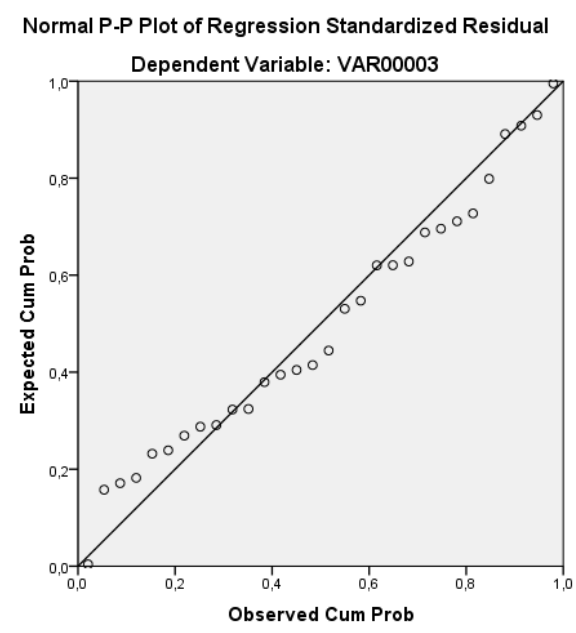

Gambar 1.3 Uji Normalitas

Kriteria sebuah data residual terdistribusi normal atau tidak, dapat dilihat dari sebaran titik-titik yang ada pada gambar. Apabila sebaran titik-titik tersebut mendekati atau rapat pada garis lurus (diagonal) maka dikatakan bahwa (data) residual 
terdistribusi normal, namun apabila sebaran titik-titik tersebut menjauhi garis maka tidak terdistribusi normal. Berdasarkan garfik di atas dapat ditarik kesimpulan bahwa data telah terdistribusi normal hal ini karena persebaran titik-titik tersebut mendekati atau rapat pada garis lurus (diagonal) maka dikatakan bahwa (data) residual terdistribusi normal.

\section{Uji Heterokedastisitas}

Pengujian heterokedastisitas dilakukan dengan membuat Scatterplot (alur sebaran) antara residual dan nilai prediksi dari variabel terikat yang telah distandarisasi. Dari uji heterokedastisitas akan dilihat apakah dalam model regresi terjadi ketidaksamaan variance dari residual satu pengamatan ke pengamatan yang lain, dengan hasil sebagai berikut:

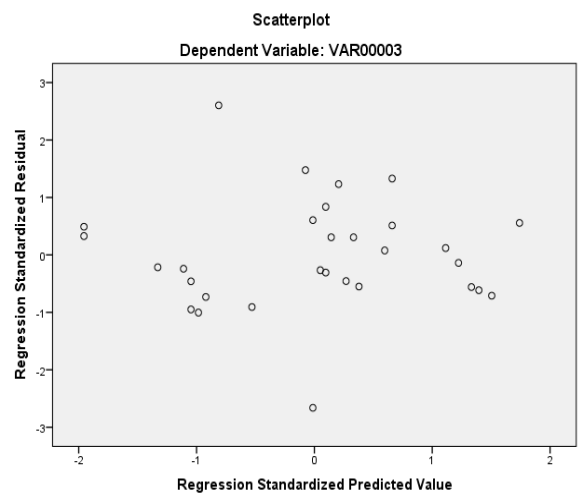

Gambar 1.4 Uji Heterokedastisitas

Berdasarkan pada gambar di atas dapat dilihat bahwa titik-titik menyebar secara acak serta tersebar tidak beraturan dan tidak membentuk pola tertentu. Berdasarkan hasil di atas, disimpulkan bahwa tidak terjadi heteroskedastisitas pada model regresi.

\section{Uji Autokorelasi}

Kemudian berdasarkan uji autokorelasi dapat kita dilihat apakah terdapat korelasi antara variabel yang ada di dalam model prediksi dengan perubahan waktu. Dimana hasil uji ini ditunjukkan oleh nilai Durbin-Watson yang tertera pada output SPSS. Angka ini akan dibandingkan dengan kriteria penerimaan atau penolakan yang akan dibuat dengan nilai $\mathrm{dL}$ dan dU ditentukan berdasarkan jumlah variabel bebas dalam model regresi $(k)$ dan jumlah sampelnya $(n)$. Nilai $\mathrm{dL}$ dan $\mathrm{dU}$ dapat dilihat pada Tabel DW dengan tingkat signifikansi (error) $5 \%(\alpha=0,05)$. Jumlah variabel bebas $(k)=2$, Jumlah sampel $(n)=40$.

Tabel 1.5

Uji Autokorelasi

Model Summaryb

\begin{tabular}{|c|c|c|c|c|c|}
\hline $\begin{array}{c}\text { Mod } \\
\text { el }\end{array}$ & $\mathrm{R}$ & $\begin{array}{c}\text { Squar } \\
\mathrm{e}\end{array}$ & $\begin{array}{c}\text { Adjuste } \\
\mathrm{d} \mathrm{R} \\
\text { Square }\end{array}$ & $\begin{array}{c}\text { Std. Error } \\
\text { of the } \\
\text { Estimate }\end{array}$ & $\begin{array}{c}\text { Durbi } \\
\mathrm{n}-\end{array}$ \\
$\begin{array}{c}\text { Watso } \\
\mathrm{n}\end{array}$ \\
\hline 1 &, $668^{\mathrm{a}}$ &, 446 &, 405 & 6,12183 & 1,664 \\
\hline
\end{tabular}

a. Predictors: (Constant), VAR00002, VAR00001

b. Dependent Variable: VAR00003

Berdasarkan ketentuan di atas, tabel Durbin-Watson menunjukkan bahwa nilai $\mathrm{dL}=1,2837$ dan nilai $\mathrm{dU}=1,56$ sehingga dapat ditentukan kriteria terjadi atau tidaknya autokorelasi seperti terlihat pada gambar di bawah ini. 


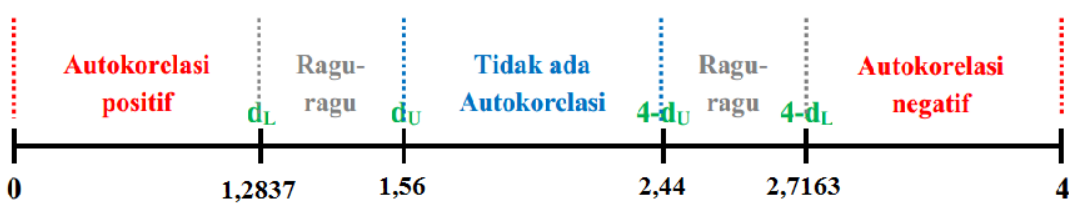

Gambar 1.6 Uji Autokorelasi

Nilai DW hitung sebesar 1,664 lebih besar dari 1,56 dan lebih kecil dari 2,44 yang artinya berada pada daerah tidak ada autokorelasi. Sehingga dapat disimpulkan bahwa dalam model regresi linier tidak terjadi autokorelasi

\section{Uji Multikolinieritas}

Berdasarkan uji multikolinearitas akan digambarkan bagaimana korelasi atau hubungan yang kuat antara dua variabel bebas atau lebih dalam sebuah model regresi berganda dengan hasil sebagai berikut :

Tabel 1.7

Uji multikolinieritas

Coefficients $^{a}$

\begin{tabular}{|r|r|}
\hline \multicolumn{2}{|c|}{ Collinearity Statistics } \\
\hline Tolerance & \multicolumn{1}{|c|}{ VIF } \\
\hline & \\
, 832 & 1,201 \\
, 832 & 1,201 \\
\hline
\end{tabular}

a. Dependent Variable:

VAR00003

Berdasarkan tabel diatas maka dapat dilihat bahwa nilai tolerance dari variabel investasisebesar 0,832 dan nilai tolerance variabel tenaga kerja sebesar 0,832 , nilai tolerance dari kedua variabel tersebut bernilai lebih besar dar 0,10 yang artinya tidak terdapat multikolinearitas pada variabel bebas dalam penelitian ini. Jika dilihat dari nilai VIF , pada variabel investasi nilai VIF sebesar 1,201 dan nilai VIF pada varibel tenaga kerja sebesar 1,201. Nilai VIF pada kedua variabel bebas ini lebih kecil dari 10, artinya tidak terdapat multikolinearitas pada variabel bebas dalam penelitian ini.

\section{Regresi Berganda}

Dalam penelitian ini akan dilihat, bagaimana pengaruh dari kompetensi kepribadian dan kompetensi pedagogik terhadap prestasi belajar siswa. Dari pengolahan data diatas, maka diperoleh hasil sebagai berikut :

Tabel 1.6

Regresi Berganda

Coefficients $^{\mathrm{a}}$

\begin{tabular}{|c|c|c|c|c|}
\hline \multirow[b]{2}{*}{ Model } & \multicolumn{2}{|c|}{$\begin{array}{c}\text { Unstandardized } \\
\text { Coefficients }\end{array}$} & \multirow{2}{*}{$\begin{array}{c}\begin{array}{c}\text { Standardized } \\
\text { Coefficients }\end{array} \\
\text { Beta }\end{array}$} & \multirow[b]{2}{*}{ Sig. } \\
\hline & B & $\begin{array}{l}\text { Std. } \\
\text { Error }\end{array}$ & & \\
\hline $\begin{array}{ll}1 & \text { (Consta } \\
\text { nt) }\end{array}$ & 24,487 & 11,181 & & ,037 \\
\hline VAR1 & 1,494 & ,510 & ,460 & ,007 \\
\hline VAR2 &, 914 & ,433 & ,331 & ,044 \\
\hline
\end{tabular}

a. Dependent Variable: VAR00003

Berdasarkan hasil di atas, maka dapat ditarik persamaan yang menggambarkan pengaruh kompetensi kepribadian dan kompetensi pedagogik yaitu 


$$
\mathrm{Y}=24,487+1,494 \mathrm{X} 1+0,914 \mathrm{X} 2
$$

Dari persamaan di atas, dapat ditarik beberapa kesimpulan. Pertama, nilai konstanta dari persamaan ini adalah 24,487 yang berarti jika setiap variabel dianggap nol maka prestasi siswa adalah 24,487. Kedua, dari persamaan di atas diperoleh koefisien kompetensi kepribadian sebesar 1,494 dan kompetensi pedagogik sebesar 0,914 yang berarti kompetensi kepribadian dan kompetensi pedagogik memiliki pengaruh yang positif $(1,494$ dan 0,914$)$ terhadap prestasi belajar siswa. Selain itu, hasil ini juga diperkuat dengan taraf signifikasi dibawah $5 \%$ yaitu $0.037,0.007$, dan 0.044 .

\section{Uji Hipotesis \\ Uji F}

Berdasarkan hasil pada tabel dibawah diketahui bahwa $f$ hitung adalah 10,875 dan signifikansi sebesar 0,00 . Hal ini menunjukkan bahwa $f_{\text {hitung }}>f_{\text {tabel }}(10,875>3,35)$ dan nilai signifikansinya $<$ nilai a $(0,00<0.05)$ yang berarti bahwa $\mathrm{H}_{0}$ ditolak dan $\mathrm{Ha}$ diterima, maka dapat disimpulkan bahwa secara simultan terdapat pengaruh yang signifikan antara kompetensi kepribadian dan kompetensi pedagogik terhadap prestasi siswa

Tabel 1.7

$$
\text { Uji F }
$$

\begin{tabular}{|c|c|c|c|c|c|}
\hline Model & $\begin{array}{l}\text { Sum of } \\
\text { Squares }\end{array}$ & $\mathrm{df}$ & $\begin{array}{l}\text { Mean } \\
\text { Squar } \\
\text { e }\end{array}$ & $F$ & Sig. \\
\hline $\begin{array}{l}1 \text { Regressio } \\
n\end{array}$ & 815,093 & 2 & $\begin{array}{r}407,5 \\
46\end{array}$ & 10,875 & $\begin{array}{r}, 00 \\
0^{\mathrm{b}}\end{array}$ \\
\hline Residual & $\begin{array}{r}1011,87 \\
4\end{array}$ & 27 & $\begin{array}{r}37,47 \\
7\end{array}$ & & \\
\hline Total & $\begin{array}{r}1826,96 \\
7\end{array}$ & 29 & & & \\
\hline
\end{tabular}

\section{ANOVA $^{a}$}

a. Dependent Variable: VAR00003

Uji T

b. Predictors: (Constant), VAR00002, VAR00001

Berdasarkan hasil di bawah, dapat diketahui bahwa variabel kompetensi kepribadian memiliki nilai $t$ hitung $>t$ tabel $(2,931>1.69726)$ hal ini sejalan dengan kompetensi pedagogik dimana $t$ hitung $>t$ tabel $(2,110>1.69726)$ berarti $\mathrm{HO}$ ditolah dan Ha diterima, sehingga dapat disimpulkan secara parsial bahwa kedua variabel bebas memiliki pengaruh yang positif dan signifikan terhadap prestasi belajar siswa.

Tabel 1.8

Uji T

\begin{tabular}{|c|c|c|c|c|c|c|}
\hline \multirow{2}{*}{\multicolumn{2}{|c|}{ Model }} & \multicolumn{2}{|c|}{$\begin{array}{l}\text { Unstandardized } \\
\text { Coefficients }\end{array}$} & \multirow{2}{*}{$\begin{array}{c}\text { Standardized } \\
\text { Coefficients } \\
\text { Beta }\end{array}$} & \multirow[b]{2}{*}{$\mathrm{t}$} & \multirow[b]{2}{*}{ Sig. } \\
\hline & & $\mathrm{B}$ & Std. Error & & & \\
\hline \multirow[t]{3}{*}{1} & (Constant) & 24,487 & 11,181 & & 2,190 & ,037 \\
\hline & VAR00001 & 1,494 &, 510 & ,460 & 2,931 & ,007 \\
\hline & VAR00002 & ,914 & ,433 & ,331 & 2,110 & ,044 \\
\hline
\end{tabular}

Coefficients $^{a}$

a. Dependent Variable: VAR00003

\section{Koefisien Determinan}

Berdasarkan tabel di bawah diperoleh nilai dari koefisien determinasi sebesar 0,446 . Nilai $R$ square ini menunjukkan bahwa variabel bebas mampu menjelaskan pengaruhnya terhadap variabel dependen sebesar $44,6 \%$. Dan sisanya $55,4 \%$ dipengaruhi oleh variabel lain yang tidah dibahas dalam penelitian ini. 
Tabel 1.9

Koefisien Determinasi

Model Summary ${ }^{b}$

\section{PENUTUP}

\begin{tabular}{|l|c|r|r|r|}
\hline Model & $\mathrm{R}$ & $\mathrm{R}$ Square & $\begin{array}{c}\text { Adjusted R } \\
\text { Square }\end{array}$ & $\begin{array}{c}\text { Std. Error } \\
\text { of the Estimate }\end{array}$ \\
\hline 1 &, $668^{\mathrm{a}}$ &, 446 &, 405 & 6,12183 \\
\hline
\end{tabular}

a. Predictors: (Constant), VAR00002, VAR00001

b. Dependent Variable: VAR00003

Pengembangan kompetensi kepribadian pada guru sangatlah penting, hal ini dapat dilihat dari banyaknya masalah yang timbul dikarenakan kurangnya kemampuan guru dalam mengajar. Oleh karena itu pengembangan dan perbaikan kompetensi guru harus dilakukan. Dimana peningkatan kemampuan guru lebih spesifiknya pada kompetensi kepribadian dan kompetensi pedagogik akan berdampak positif pada prestasi siswa. Hal ini diperkuat dengan hasil artikel ini yaitu ada pengaruh yang positif dan signifikan antara kompetensi kepribadian dan kompetensi pedagogik terhadap prestasi siswa. Sehingga akan meningkatkan kemampuan guru dari segi prilaku dimana guru harus menjadi bahan panutan murid. Selain kompetensi kepribadian, guru juga harus meningkatkan kemampuan pedagogik dimana, pengembangan kemampuan pedagogik dapat memotivasi siswa dan mempermudah siswa dalam memahami pelajaran lewat berbagai macam strategi dalam pembelajaran. Sehingga pada akhirnya guru dalam meningkatkan prestasi siswa dan akan tercipta hubungan yang baik antara peserta didik dan pendidik.

\section{DAFTAR PUSTAKA}

Darojah, R. N \& Hadijah, S. H. 2016. Analisis Pengaruh Kompetensi Kepribadian Guru dengan Motivasi Belajar Sebagai Variabel Intervening Terhadap Prestasi Belajar Siswa Kelas X Administrasi Perkantoran. Jurnal Pendidikan Manajemen Perkantoran. Volume 1, Nomor 1, Agustus 2016, Halaman 115-125.

Dewi, Luh Retiantari, Naswan Suharsono, lyus akhmad Haris. (2014). Pengaruh Kompetensi Pedagogik Dan Kompetensi Profesional Terhadap Hasil Belajar Siswa Dalam Mata Pelajaran Ekonomi Kelas X SMAN 4 Singaraja. Jurnal Pendidikan Ekonomi Undiksha. (Vol: 4 No: 1 Tahun: 2014)

Hendri, Edi. 2010 Guru Berkualitas: Profesional dan Cerdas Emosi, Jurnal Saung Guru. Vol.1 No.2.

Janawi. 2011. Kompetensi Guru Citra Guru Profesional. Bangka Belitung : Shiddiq Press.

Lailatussaadah. 2015. Upaya Peningkatan Kinerja Guru. Intelektualita, 3(1): 15-25

Oktradiksa, Ahwy. 2012, Perkembanngan Kualitas Kepribadian Guru, Jurnal Pendidikan Islam, Vol. 6 No 2, hal 231-248 ISSN 1979-1739

Purwanti . 2013, guru dan kompetensi kepribadian, jurnal visis ilmu pendidikan FKIP Untan. Vol 10 No 1 hal 1074-1087

Rohmah, Kholifatul Kurnia dan Marimin. 2015, Pengaruh Persepsi Siswa Mengenai Keterampilan Mengajar, Kompetensi Kepribadian, Dan Kompetensi Sosial Guru, Terhadap Prestasi Belajar Siswa Program Studi Administrasi Perkantoran di SMK Negeri 1 Purwodadi, Jurnal Pendidikan Ekonomi Dinamika Pendidikan Vol. X No. 1, Juni 2015 Hal. $28-41$

Sudjana, Nana. 2002. Dasar-Dasar Proses Belajar Mengajar. Bandung. Remaja Rosdakarya Susanna. (2014). Kepribadian Guru PAI dan Tantangan Globalisasi. Jurnal Mudarrisuna , Vol.4 No.2, 376 - 396.

Susanti, Ika Nawal dan Rizka Qurroti Aini. 2015, pengaruh kompetensi pedagogik guru terhadap prestasi belajar matematika siswa kelas VII MTS Al-Amiriyyah Blokagung Banyuwangi, Darussalam: Jurnal Pendidikan, Komunikasi, dan Pemikiran Hukum Islam Vol 6, No. 2: 125-138. April 2015. Issn: 1978 - 4767 
Umar, Japar, Dadang Hidayat dan Wardaya.2014, Pengaruh Persepsi Siswa Tentang Kompetensi Pedagogik Guru Dan Motivasi Belajar Siswa Terhadap Prestasi Belajar Siswa Pada Mata Pelajaran Bubut Lanjut 1, Journal of Mechanical Engineering Education, Vol.1, No.1, Juni 2014

Wibowo dan Hamrin. 2012. Menjadi Guru Berkarakter. Yogyakarta: Pustaka Belajar. 